\title{
PENGETAHUAN DAN SIKAP IBU TERHADAP KURANG GIZI PADA DI KOMPLEK VETERAN PERCUT SEI TUAN
}

\author{
Roswanita Siregar \\ Universitas Haji Sumatera Utara, Medan, Indonesia \\ roswanita89@gmail.com
}

\begin{abstract}
ABSTRAK
Nutrisi adalah elemen yang terdapat dalam makanan dan dapat digunakan secara langsung oleh tubuh seperti karbohidrat, protein, lemak, vitamin, mineral, dan air. Nutrisi yang seimbang dibutuhkan oleh tubuh terutama pada bayi yang masih dalam masa pertumbuhan. Dimana pertumbuhan berlangsung cepat seorang balita membutuhkan makanan yang berkualitas dan kuantitas yang tepat dan seimbang.

Desain penelitian deskriptif korelasional dengan pendekatan cross-sectional. Populasi adalah keseluruhan objek penelitian atau objek yang diteliti. Populasi dalam penelitian ini adalah ibu yang memiliki anak di komplek Dusun VIII yang berjumlah 30 orang. Teknik pengambilan sampel menggunakan total sampling yaitu dengan menggunakan semua objek yang dijadikan sampel dalam populasi

Hasil penelitian menunjukkan bahwa tingkat pengetahuan dari 30 responden yang disurvei ada 9 responden berpengetahuan baik mayoritas responden mempunyai sifat gizi positif sebanyak 8 responden $(26,7 \%)$. Dari 16 responden yang berpengetahuan cukup mayoritas responden memiliki sikap positif tentang gizi sebanyak 10 responden $(33,3 \%)$ dan dari 5 responden berpengetahuan kurang sebagian besar memiliki sikap negatif sebanyak 4 responden $(13,3 \%)$.

Berdasarkan hasil penelitian dapat disimpulkan bahwa responden memiliki pengetahuan yang cukup dan memiliki sikap yang positif. Diharapkan petugas kesehatan dapat memberikan penyuluhan guna meningkatkan pengetahuan dan sikap ibu tentang gizi pada bayi.
\end{abstract}

Kata Kunci: Pengetahuan, Sikap, Malnutrisi 


\begin{abstract}
Nutrition is an element found in food and can be used directly by the body as its terms of carbohydrates, proteins, fats, vitamins, minerals, and water. Balanced nutrition needed by the body, especially in infants who are still in its infancy. Where growth takes place quickly a toddler who needed food quality and quantity is appropriate and balanced.

The study design was descriptive correlational cross-sectional approach. Population is the whole object of research or objects examined. The population in this study were mothers who have children in the complex veteran hamlet VIII total of 30 people. Sampling technique is using a total sampling is by using all objects made in the sample

population

The results showed that the level of knowledge of 30 respondents surveyed are 9 respondents were knowledgeable good majority of respondents have a positive nutritional properties as many as 8 respondents (26.7\%). Of the 16 respondents who are knowledgeable enough majority of respondents have a positive attitude about the nutritional as many as 10 respondents (33.3\%) and from 5 less knowledgeable respondents mostly had a negative attitude as much as 4 respondents (13.3\%).

Based on the research results can be concluded that the respondents have sufficient knowledge and have a positive attitude. It is expected that health workers can provide counseling in order to increase the knowledge and attitudes of mothers about nutrition in infants.
\end{abstract}

Keywords: Knowledge, Attitude, Malnourished

\title{
PENDAHULUAN
}

\subsection{Latar Belakang}

Gizi adalah elemen yang terdapat dalam makanan dan dapat dimanfaatkan secara langsung oleh tubuh seperti hal nya karbohidrat, protein, lemak, vitamin, mineral, dan air. Gizi yang seimbang dibutuhkan oleh tubuh, terlebih pada balita yang masih dalam masa pertumbuhan. Dimana tumbuh kembang balita yang berlangsung secara cepat dibutuhkan makanan dengan kualitas dan kuantitas yang tepat dan seimbang. (Sapada, 2012).

Masa balita merupakan masa dimana anak memerlukan asupan gizi yang sangat banyak agar sel-sel otak mampu berkembang optimal sehingga anak bisa tumbuh cerdas dan membentuk daya tahan tubuh anak supaya tidak mudah sakit (Hoesada, 2014).

Apabila seorang anak terkena defisiensi gizi maka kemungkinan besar sekali anak akan mudah terkena infeksi. Gizi ini sangat berpengaruh terhadap nafsu makan, kehilangan bahan makanan misalnya melalui diare dan muntah-muntah, serta metabolisme makanan pada anak. Selain itu juga dapat diketahui bahwa infeksi menghambat reaksi imunologis yang normal dengan menghabiskan sumber-sumber energy tubuh (Proverawati, 2011)

Akibat kekurangan gizi terhadap proses tubuh menyebabkan gangguan pada proses-proses pertumbuhan menjadi lambat, berkurangnya tenaga untuk bergerak, pertahanan tubuh jadi berkurang, terganggunya fungsi otak secara permanen, berprilaku tidak tenang mudah tersinggung, cengeng dan apatis (Almatsier, 2004)

Ada beberapa faktor yang sering menjadi penyebab gangguan gizi, baik langsung maupun tidak langsung. Sebagai penyebab langsung gangguan gizi khususnya gangguan gizi pada bayi dan balita adalah tidak sesuai jumlah gizi yang mereka peroleh 
dari makanan dengan kebutuhan tubuh mereka. Beberapa faktor yang secara tidak langsung mendorong terjadinya gangguan pada gizi terutama pada anak balita (Proverawati, 2010).

Balita yang mengalmi Gizi buruk akut menurut sensus Word Health Organization (WHO) tahun 2007 menunjukkan 49\% dari 10,4 juta kematian yang terjadi pada anak di bawah lima tahun. Di negara berkembang kasus kekurangan gizi tercatat sebanyak 50\% anak-anak Asia, 30\% anak Afrika dan 20\% anak-anak di Amerika latin. Dari kondisi tubuh balita yang menderita gizi buruk memiliki berat badan di bawah rata-rata, berat badan/umur balita $<60 \%$ berada di bawah garis merah sehingga tergolong KEP berat (petiknews.com).

Kecukupan gizi sangat penting bagi kesehatan balita, dimana seluruh pertumbuhan dan kesehatan balita erat kaitannya dengan masukan makanan yang memadai. Pertumbuhan dan perkembangan yang optimal pada balita memerlukan makanan yang sesuai dengan balita yang sedang tumbuh (Maryunani, 2010 ).

Masalah gizi di Indonesia dan Negara berkembang pada umumnya masih didominasi oleh masalah kurang energy protein (KEP), masalah anemia zat besi, masalah gangguan akibat kekurangan yodium (GAKY), masalah kurang vitamin A (KVA) dan masalah obesitas terutama di kota-kota besar. (Departemen Gizi dan kesehatan masyarakat, 2010).

Setiap tahun diperkirakan 7\% anak balita Indonesia (sekitar 300.000 jiwa) meninggal. Ini berarti setiap 2 menit terjadi kematian satu anak balita \& 170.000 anak $(60 \%)$ di antaranya akibat gizi buruk. Dari seluruh anak usia 4-24 bulan yang berjumlah seperempat sekarang berada dalam kondisi kurang gizi (Herwin, 2004).

Berdasarkan dari data departemen Kesehatan Indonesia, pada tahun 2004 kasus gizi kurang dan gizi buruk sebanyak 5,1 juta, kemudian pada tahun 2005 turun menjadi 4,42 jiwa pada balita. tahun 2006 turun menjadi 4,2 juta (944.246 jiwa di antaranya kasus gizi buruk) dan tahun 2007 turun lagi menjadi 4,1 juta (755.397 jiwa di antaranya kasus gizi buruk) (petiknews.com).

Data Riset Kesehatan Dasar (Riskesdas) Provinsi Sumatera Utara Tahun 2012 menunjukkan bahwa status gizi kurang balita di Sumatera Utara pada Tahun 2012 mencapai $22,7 \%$. Sebagian besar balita ditimbang di posyandu yaitu sebesar $63 \%$, sedangkan ditimbang di puskesmas sebesar 15\%. Secara umum 32\% balita tidak mempunyai KMS, 51\% mempunyai KMS tetapi tidak dapat menunjukkan. Persentase anak yang ibunya dapat menunjukan KMS turun seiring naiknya umur anak (40\% anak umur 6-11 bulan, dan 8\% anak umur 48-59 bulan). Hal ini dapat disebabkan KMS yang dimiliki anak yang lebih tua sudah banyak yang hilang atau dibuang. Cakupan penimbangan balita (D/S) di Kota Medan dalam Profil Kesehatan Sumatera Utara Tahun 2007 masih tergolong sangat rendah yaitu dari 137.396 balita yang ada hanya 34.470 balita yang ditimbang $(25,09 \%)$. Berdasarkan Profil Kesehatan Kota Medan (2008), Balita Bawah Garis Merah (BGM) di Kota Medan Tahun 2008 berjumlah 1.572 orang, sedangkan Tahun 2007 berjumlah 625 orang yang berarti terjadi peningkatan kasus. Hal ini disebabkan pada Bulan Mei Tahun 2008 dilaksanakan operasi timbang yang wajib dilaksanakan oleh seluruh puskesmas dan puskesmas pembantu sehingga balita yang selama ini tidak pernah datang ke posyandu dapat terjaring pada saat operasi ini.

Secara nasional, pada tahun 2006 berdasarkan data Pemantauan Status Gizi (PSG) didapat prevalensi gizi kurang sebesar 20,8\%. Berdasarkan data Riset Kesehatan Dasar (Riskerdas) tahun 2007 dari sekitar 25 juta balita, sebanyak 4,6 juta diantaranya menderita gizi kurang dimana berat badannya tidak memenuhi berat badan normal 
menurut umurnya. Target Millenium Development Goals (MDGs) yaitu menurunkan jumlah balita gizi kurang menjadi separuh dari keadaan sekarang atau 18,4\% pada tahun 2007 menjadi kurang dari 10\% pada tahun 2020 (Depkes RI, 2009).

Status gizi buruk pada anak balita di Sumatera Utara pada tahun 2003 yang tergolong sangat tinggi yaitu sebesar $12,35 \%$ dan gizi kurang 18,59\%. Gizi kurang pada anak akan menghambat pertumbuhan dan kurangnya zat tenaga dan kurang protein (zat pembangun) sehingga perlu diperhatikan menu yang seimbang khususnya pada anakanak (petiknews.com) dan pada tahun 2012 terdapat sebanyak 746 status gizi buruk di Sumatera Utara dan angka kematian balita di Sumatera Utara sebesar 54/1000 kelahiran hidup (Dinkes, 2012).

Dengan data di atas perlu dilakukan upaya - upaya untuk menolong keluarga dan balita yang mempunyai masalah dengan gizi. Sehingga mereka mampu memelihara kesehatan serta gizi keluarga dan balitanya. Menu seimbang sangat penting terutama pada awal pertumbuhan balita, yaitu saat preferensi balita terhadap makanan sedang dibentuk (Prita, 2009).

Menurut hasil penelitian Manurung (2010), bahwa ada pengaruh pengetahuan gizi terhadap penyediaan menu seimbang, yaitu terjadi peningkatan pengetahuan, sikap dalam penyediaan menu seimbang untuk balita. Jadi diharapkan bahwa setelah penyuluhan dilakukan pengetahuan ibu mengatasi kurang gizi pada balita dapat dilakukan.Pengetahuan ibu sebelum penyuluhan gizi adalah cukup $(78,57 \%)$ dan sesudah penyuluhan menjadi baik $(90,48 \%)$. Dan tindakan sebelum penyuluhan cukup $(14,29 \%)$ dan setelah dilakukan penyuluhan menjadi baik $(42,86 \%)$.

Berdasarkan survey yang dilakukan peneliti pada tanggal 29 maret 2015 di Komplek Veteran Dusun VIII Kecamatan Percut Sei Tuan dari 10 orang ibu yang mempunyai Balita, ada 7 balita yang mengalami kurang gizi pada balita tersebut, yang seharusnya BB balita $10 \mathrm{~kg}$ dari umur 1-5 tahun dan setelah di lakukan penimbangan ternyata berat badan anak kurang dari batas normal. Salah satu penyebab gizi kurang di Komplek Veteran adalah kurangnya pengetahuan ibu tentang pemberian makanan yang bergizi pada balita.

\subsection{Rumusan Masalah}

Berdasarkan latar belakang diatas, maka permasalahan dapat di rumuskan sebagai berikut “ Apakah ada Hubungan Pengetahuan Dan Sikap Ibu Terhadap Kurang Gizi Pada Balita Di Komplek Veteran Dusun VIII Kecamatan Percut Sei Tuan Tahun 2015?".

\subsection{Tujuan Penelitian}

\subsubsection{Tujuan Umum}

Untuk mengetahui Hubungan Pengetahuan Dan Sikap Ibu Terhadap Kurang Gizi Pada Balita Di Komplek Veteran Dusun VIII Kecamatan Percut Sei Tuan Tahun 2015.

1.3.2 Tujuan Khusus

a. Untuk mengidentifikasi tingkat pengetahuan ibu terhadap kurang gizi pada balita

b. Untuk mengidentifikasi bagaimana sikap ibu terhadap kurang gizi pada balita.

c. Untuk mengetahui hubungan pengetahuan dan sikap ibu terhadap kurang gizi pada balita di Komplek Veteran Dusun VIII Kecamatan Percut Sei Tuan 


\section{METODE PENELITIAN}

\subsection{Jenis dan Desain Penelitian}

3.1.1 Jenis Penelitian

Desain penelitian yang digunakan dalam penelitian ini bersifat deskritif korelational dengan pendekatan cross sectional (Arikunto, 2006).

\subsubsection{Desain Penelitian}

Desin penelitian adalah desain"cross sectional" dengan desain ini bertujuan untuk mengetahui hubungan pengetahuan dan sikap ibu terhadap kurang gizi pada balita di Komplek Veteran Dusun VIII Kecamatan Percut Sei Tuan Tahun 2015.

\subsection{Lokasi Dan Waktu Penelitian}

\subsubsection{Lokasi Penelitian}

Lokasi penelitian ini dilaksanakan di Komplek veteran Dusun VIII Kecamatan Percut Sei Tuan tahu 2015. Pemilihan lokasi penelitian ini dikarenakan terdapat balita yang mengalami gizi kurang.

\subsubsection{Waktu Penelitian}

Penelitian ini dilaksanakan pada tanggal 7 September sampai dengan 28 September tahun 2015 dari proses pengajuan judul, observasi, pengambilan data, pembagian kuesioner, sampai dengan pengolahan data.

\subsection{Populasi dan Sampel Penelitian}

3.3.1. Populasi

Populasi adalah keseluruhan objek penelitian atau objek yang di teliti. Populasi dalam penelitian ini adalah ibu yang mempunyai balita di komplek veteran dusun VIII, Adapun jumlah ibu yang mempunyai balita di Dusun VIII Komplek Veteran dari bulan Januari sampai bulan Maret sebanyak 30 orang .

\subsubsection{Sampel}

Sampel adalah sebagian atau wakil dari populasi yang diteliti. Untuk menentukan individu atau obyek yang menjadi sampel, digunakan Total Sampling yaitu dengan menggunakan seluruh objek populasi menjadi sampel penelitian sebanyak 30 orang. Sampel Inkulusi Dalam Penelitian ini adalah Ibu - Ibu yang mempunyai Balita.

\section{HASIL DAN PEMBAHASAN}

\subsection{Hasil Penelitian}

Penelitian ini dilakukan di Komplek Veteran Dusun VIII Kecamatan Percut Sei Tuan. Penelitian ini dilaksanakan pada tanggal 7 September sampai dengan 28 September tahun 2015 dengan jumlah responden sebanyak 30 orang. Pengumpulan data dilakukan dengan menggunakan lembar observasi untuk mengetahui karakteristik responden dan pemberian kuesioner dengan 18 pertanyaan untuk pengetahuan dan 18 pertanyaan untuk sikap ibu tentang kurang gizi pada balita yang sudah divalidkan. Penelitian ini menggunakan desain Korelasi untuk mengetahui Hubungan Pengetahuan dan Sikap Ibu terhadap Kurang Gizi Pada Balita di Komplek Veteran Dusun VIII Kecamatan Percut Sei Tuan.

\subsection{Analisa Univariat}

a. Data Demografi Ibu yang memiliki Balita di Komplek Veteran Dusun VIII Kecamatan Percut Sei Tuan

\section{Tabel2}

\section{Distribusi Frekuensi Berdasarkan Karakteristik Responden}




\begin{tabular}{|c|c|c|c|}
\hline \multirow{2}{*}{ No } & \multirow{2}{*}{ Karakteristik Responden } & \multicolumn{2}{|l|}{ Jumlah } \\
\hline & & $\mathrm{N}$ & Persentase (\%) \\
\hline \multirow[t]{5}{*}{1} & Umur (tahun) & & \\
\hline & - $\quad 20-25$ tahun & 8 & 26,7 \\
\hline & $-\quad 26-30$ tahun & 18 & 60,0 \\
\hline & - $\quad 31-35$ tahun & 4 & 13,3 \\
\hline & Jumlah & 30 & 100 \\
\hline \multirow[t]{6}{*}{2} & Pendidikan & & \\
\hline & $-\quad \mathrm{SD}$ & 2 & 6,7 \\
\hline & - $\quad$ SMP & 4 & 13,3 \\
\hline & - $\quad$ SMA & 21 & 70,0 \\
\hline & - $\quad$ Perguruan Tinggi & 3 & 10,0 \\
\hline & Jumlah & 30 & 100 \\
\hline \multirow[t]{5}{*}{3} & Pekerjaan & & \\
\hline & - $\quad$ Ibu Rumah Tangga & 18 & 60,0 \\
\hline & - Wiraswasta & 10 & 33,3 \\
\hline & - PNS & 2 & 6,7 \\
\hline & Jumlah & 30 & 100 \\
\hline \multirow[t]{4}{*}{4} & Paritas & & \\
\hline & - $\quad 1-2$ orang & 22 & 73,3 \\
\hline & $-\quad \geq 3$ orang & 8 & 26,7 \\
\hline & Jumlah & 30 & 100 \\
\hline
\end{tabular}

Berdasarkan tabel 2 di atas diketahui bahwa karakteristik responden berdasarkan umur mayoritas responden berumur antara 26-30 tahun sebanyak 18 responden (60\%). Tingkat pendidikan responden sebagian besar berlatar pendidikan SMA sebanyak 21 responden $(70,0 \%)$ dengan pekerjaan responden mayoritas sebagai Ibu rumah tangga sebanyak 18 responden (60\%). Sedangkan berdasarkan jumlah anak, mayoritas responden memiliki 1-2 orang anak sebanyak 22 responden $(73,3 \%)$.

b. Pengetahuan Ibu tentang Kurang Gizi Pada Balita

Tabel 3

Distribusi Frekuensi Pengetahuan Ibu terhadap Kurang Gizi Pada Balita

di Komplek Veteran Dusun VIII Kecamatan Percut Sei Tuan Tahun 2015

\begin{tabular}{|c|c|c|c|}
\hline No & Pengetahuan & Jumlah & Persentase $(\%)$ \\
\hline 1 & Baik & 9 & 30,0 \\
\hline 2 & Cukup & 16 & 53,3 \\
\hline 3 & Kurang & 5 & 16,7 \\
\hline & Total & 30 & 100 \\
\hline
\end{tabular}

Berdasarkan tabel 3 diatas diketahui bahwa mayoritas responden memiliki pengetahuan yang cukup tentang Kurang Gizi Pada Balita di Komplek Veteran Dusun VIII Kecamatan Percut Sei Tuan sebanyak 16 responden $(53,3 \%)$.

c. Sikap Ibu tentang Kurang Gizi Pada Balita

Tabel 4

Distribusi Frekuensi Sikap Ibu terhadap Kurang Gizi Pada Balita di Komplek Veteran Dusun VIII Kecamatan Percut Sei Tuan Tahun 2015

\begin{tabular}{llll}
\hline No & Sikap & Jumlah & Persentase (\%) \\
\hline 1 & Negatif & 11 & 36,7 \\
2 & Positif & 19 & 63,3 \\
\hline & Total & 30 & 100,0 \\
\hline
\end{tabular}


Berdasarkan tabel 4 diatas bahwa mayoritas responden memiliki sikap yang cukup tentang Kurang Gizi Pada Balita di Komplek Veteran Dusun VIII Kecamatan Percut Sei Tuan sebanyak 19 responden $(63,3 \%)$.

\subsection{Analisis Bivariat}

Analisa Bivariat dimaksudkan untuk mengetahui hubungan masing-masing variabel independen dan dependen.Pengujian ini menggunakan uji chi-square. Dikatakan ada hubungan yang bermakna secara statistik jika diperoleh $\mathrm{p}<0,05$ ( Notoatmodjo, $2010 ; 183)$.

a. Hubungan Pengetahuan dengan Sikap Ibu tentang Kurang Gizi Pada Balita di Komplek Veteran Dusun VIII Kecamatan Percut Sei Tuan Tabel 5

Tabulasi Silang antara Pengetahuan dan Sikap Ibu terhadap Kurang Gizi Pada Balita di Komplek Veteran Dusun VIII Kecamatan Percut Sei Tuan Tahun 2015

\begin{tabular}{|c|c|c|c|c|c|c|c|c|}
\hline \multirow{3}{*}{ Pengetahuan } & \multicolumn{4}{|c|}{ Sikap Ibu } & & & \multirow{3}{*}{$\mathrm{X}_{\text {hitung }}^{2}$} & \multirow{3}{*}{$\mathrm{P}$} \\
\hline & \multicolumn{2}{|c|}{ Negatif } & \multicolumn{2}{|c|}{ Positif } & \multicolumn{2}{|c|}{ Total } & & \\
\hline & $\mathrm{F}$ & $\%$ & $\mathrm{~F}$ & $\%$ & $\mathrm{~F}$ & $\%$ & & \\
\hline Baik & 1 & 3,3 & 8 & 26,7 & 9 & 30,0 & & \\
\hline Cukup & 6 & 20,0 & 10 & 33,3 & $\begin{array}{l}1 \\
6\end{array}$ & 53,3 & & \\
\hline Kurang & 4 & 13,3 & 1 & 3,3 & 5 & 16,7 & 6,579 & 0,037 \\
\hline Total & 11 & 36,7 & 19 & 63,3 & $\begin{array}{l}3 \\
0\end{array}$ & 100,0 & & \\
\hline
\end{tabular}

Berdasarkan tabel 5 di atas diketahui bahwa dari 30 responden yang diteliti terdapat 9 responden yang berpengetahuan baik sebagian besar responden memiliki sifat positif tentang gizi balita yaitu sebanyak 8 responden(26,7\%) .Dari 16 responden yang berpengetahuan cukup sebagian besar responden memiliki sikap positif tentang gizi balita yaitu sebanyak 10 responden $(33,3 \%)$ dan dari 5 responden yang berpengetahuan kurang sebagian besar memiliki sikap yang negatif sebanyak 4 responden $(13,3 \%)$.

Hasil uji statistik chi square didapat nilai $p$ value $=0,037(\mathrm{p}<0,05)$ sehingga Hipotesis Alternatif (Ha) diterima yang berarti ada hubungan yang signifikan antara Pengetahuan dengan Sikap Ibu tentang Kurang Gizi Pada Balita di Komplek Veteran Dusun VIII Kecamatan Percut Sei Tuan. Hasil $X^{2}$ hitung $=6,579$ artinya bahwa ibu yang memiliki pengetahuan yang baik cenderung 6,579 kali memiliki sikap yang positif mengenai gizi pada balita dibandingkan ibu yang memiliki pengetahuan yang kurang.

\subsection{Pembahasan}

4.5.1 Pengetahuan Ibu terhadap Kurang Gizi Pada Balitadi Komplek Veteran Dusun VIII Kecamatan Percut Sei Tuan

Berdasarkan hasil penelitian diketahui bahwa mayoritas responden memiliki pengetahuan yang cukup terhadap Kurang Gizi Pada Balita di Komplek Veteran Dusun VIII Kecamatan Percut Sei Tuan sebanyak 16 responden (53,3\%). Hal ini dikarenakan secara umum banyak faktor-faktor yang mempengaruhi pengetahuan yang setiap individu mempunyai pengetahuan yang berbeda.Adapun faktor-faktor yang mempengaruhi pengetahuan setiap individu adalah pendidikan, sumber informasi, sosial budaya, ekonomi, lingkungan, dan pengalaman.Dalam penelitian ini faktor yang 
mempengaruhi pengetahuan ibu tentang gizi yang kurang adalah tingkat pendidikan ibu yang rendah.

Pengetahuan dapat diperoleh dari pendidikan baik bersifat formal ataupun nonformal. Menurut Notoatmodjo (2010), mengatakan bahwa tingkat pendidikan akan mempengaruhi pengetahuan seseorang sehingga membuat seseorang berpandangan luas, berpikir dan bertindak rasional karena semakin tinggi tingkat pendidikan responden maka tingkat pengetahuannya akan semakin baik, sehingga responden mudah menerima informasi dan semakin banyak pula pengetahuan yang dimilikinya.Responden yang memiliki tingkat pendidikan tinggi cenderung memiliki tingkat pengetahuan yang baik atau cukup.Selain pendidikan dan sumber informasi yang sulit, dalam penelitian ini usia juga mempengaruhi tingkat pengetahuan.

Dari hasil penelitian menunjukkan bahwa distribusi responden berdasarkan karakteristik umur yang terbanyak yaitu umur 25-35 tahun. Menurut Elizabeth B. Hurlock (2012) rentang umur 25-35 tahun merupakan tahap perkembangan dewasa awal.Masa ini merupakan masa dimana para ibu belum mengetahui lebih banyak informasi dan pengetahuan tentang gizi karena kurangnya pengalaman dan pengetahuan dari luar.

Menurut Sediaoetama (2009) bahwa pendidikan adalah variabel yang mempunyai peran cukup penting terhadap seseorang terutama dalam mengambil keputusan terhadap suatu masalah karena dengan pendidikan yang memadai akan meningkatkan pengetahuan seseorang tentang gizi. Semakin baik pengetahuan gizi seseorang, maka orang itu akan semakin memperhatikan kuantitas dan kualitas pangan yang akan dikonsumsinya. Orang yang tidak mempunyai cukup pengetahuan tentang gizi, akan memilih makanan yang baik menurut panca indranya dan tidak mengadakan pilihan makanan berdasarkan nilai gizi makanannya. Sebaliknya orang yang semakin baik pengetahuan tentang gizinya makan akan lebih banyak mempergunakan pertimbangan rasional dan pengetahuannya sebagai dasar sebelum mengkonsumsi makanan tersebut.

Menurut asumsi peneliti, bahwa Ibu-ibu yang memiliki pengetahuan cukup dan memiliki anak status gizi kurang bisa disebabkan karena kurang minatnya ibu terhadap ilmu pengetahuan yang ada sehingga ibu sudah merasa puas dengan pengetahuan yang sudah dimilikinya pada saat ini. Dari penelitian ini ibu dengan pengetahuan baik masih ada memiliki anak yang berstatus gizi kurang dan lebih. Ketidaksesuaian ini bisa terjadi karena pengetahuan yang baik belum tentu diikuti dengan perilaku dan sikap dalam pola asuh anak.

4.5.2 Sikap Ibu tentang Kurang Gizi Pada Balita di Komplek Veteran Dusun VIII Kecamatan Percut Sei Tuan

Berdasarkan hasil penelitian menunjukkan bahwa mayoritas responden memiliki sikap yang positif tentang Kurang Gizi Pada Balita di Komplek Veteran Dusun VIII Kecamatan Percut Sei Tuan sebanyak 19 responden (63,3\%) dan selebihnya 11 responden $(36,7 \%)$ memiliki sikap yang negatif tentang gizi pada balita.Hal ini sejalan dengan tingkat pengetahuan responden yang dominan cukup dan berpengaruh terhadap sikap yang positif pula.

Sikap positif ini merupakan aset yang dapat digunakan oleh pemerintah setempat dalam upaya peningkatan status gizi balita, sebab sikap yang baik memiliki kontribusi yang cukup signifikan terhadap perilaku masyarakat dalam usaha pemenuhan gizi balita. Tetapi suatu sikap tidak selalu terwujud dalam suatu tindakan (Notoatmodjo, 2010). Hal ini sesuai dengan kenyataan bahwa sikap yang positif terhadap nilai-nilai kesehatan terutama nilai gizi tidak selalu terwujud dalam suatu tindakan nyata dan ini terbukti masih ada ibu yang kurang dalam memperhatikan status gizi balitanya. 
Menurut asumsi peneliti, bahwa sikap responden yang positif mengenai gizi pada balita cenderung akan diikuti oleh tindakan yang baik dalam memberikan asupan makanan gizi seimbang pada balita sesuai dengan kebutuhan nutrisi yang diperlukan pada balitanya.

4.5.3 Hubungan Pengetahuan dengan Sikap Ibu tentang Kurang Gizi Pada Balita di Komplek Veteran Dusun VIII Kecamatan Percut Sei Tuan

Berdasarkan hasil tabulasi silang antara Pengetahuan denganSikap Ibu tentang Kurang Gizi Pada Balitadi Komplek Veteran Dusun VIII Kecamatan Percut Sei Tuan dapat dijelaskan bahwa dari 30 responden yang diteliti terdapat 9 responden yang berpengetahuan baik sebagian besar responden memiliki sifat positif tentang gizi balita yaitu sebanyak 8 responden(26,7\%). Dari 16 responden yang berpengetahuan cukup sebagian besar responden memiliki sikap positif tentang gizi balita yaitu sebanyak 10 responden $(33,3 \%)$ dan dari 5 responden yang berpengetahuan kurang sebagian besar memiliki sikap yang negatif sebanyak 4 responden $(13,3 \%)$.

Hasil uji statistik chi square didapat nilai $\mathrm{p}$ value $0,037(\mathrm{p}<0,05)$ sehingga Hipotesis Alternatif (Ha) diterima yang berarti ada hubungan yang signifikan antara Pengetahuan dengan Sikap Ibu tentang Kurang Gizi Pada Balita di Komplek Veteran Dusun VIII Kecamatan Percut Sei Tuan. Hasil X ${ }^{2}$ hitung sebesar 6,579 artinya bahwa ibu yang memiliki pengetahuan yang baik cenderung 6,579 kali memiliki sikap yang positif mengenai gizi pada balita dibandingkan ibu yang memiliki pengetahuan yang kurang.

Menurut Notoatmodjo (2010), pengetahuan merupakan domain yang sangat penting untuk terbentuknya tindakan seseorang karena dari pengalaman dan penelitian juga terbukti bahwa prilaku yang didasari oleh pengetahuan akan lebih bagus dari pada perilaku yang tidak didasari pengetahuan. Sebelum seseorang mangadopsi perilaku, dia harus tahu terlebih dahulu apa arti manfaat prilaku tersebut bagi dirinya atau keluarganya. Dari hasil penelitian disebutkan bahwa dengan pengetahuan ibu tentang gizi yang kurang, secara langsung akan mempengarui pola sikap dan prilaku ibu dalam memberikan asupan makanan yang bergizi kepada balitanya. Hal ini dikerenakan pengetahuan merupakan salah satu domain atau gambaran terhadap pola sikapnya dan prilakunya dalam memberikan asupan makanan yang bergizi kepada balitanya sehingga pengetahuan ibu tentang gizi dapat mempengaruhi status gizi pada balita.

Pengetahuan sangat berpengaruh terhadap sikap ibu tentang status gizi pada balita. Seseorang yang hanya tamat SD belum tentu tidak mampu dalam menyusun makanan yang memenuhi persyaratan gizi untuk balitanya dibanding orang yang memilki pendidikan yang lebih tinggi, karena bila ibu rajin mendengarkan informasi dan selalu turut serta dalam penyuluhan gizi tidak mustahil pengetahuan gizi siibu akan bertambah dan menjadi lebih baik. Hanya saja perlu dipertimbangkan bahwa tingkat pendidikan ibu dan mudah tidaknya siibu menyerap dan memahami pengetahuan gizi yang diperolehnya.

\subsection{Keterbatasan Dalam Penelitian}

Dalam Penelitian ini, Peneliti telah berupaya semaksimal mungkin untuk memperoleh data yang sebenarnya dan mengontrol kondisi yang berkaitan dengan proses dan hasil penelitian secara optimal, namun berbagai kendala tidak jarang muncul sehingga berbagai kelemahan dan keterbatasan padasaat pelaksanaan penelitian ini.

1. Keterbatasan waktu dalam membagikan kuesioner sehingga dapat mempengaruhi hasil yang didapat.

2. Kesulitan dalam mengumpulkan data di karenakan sebagian ibu tidak berada dirumah saat peneliti membagikan kuesioner. 
Karena keterbatasan-keterbatasan itu menyebabkan hasil penelitian ini peerlu pengkajian yang lebih seksama di masa mendatang dengan melihat faktor di luar keterbatasan sekarang serta dengan metode yang lebih bervariasi untuk memberikan keyakinan terhadap hasil yang diperoleh, sehingga hasilnya lebih bermanfaat dan dapat diterapkan.

\section{KESIMPULAN DAN SARAN}

\subsection{Kesimpulan}

Dari hasil penelitian dan pembahasan tentang Pengetahuan dengan Sikap Ibu tentang Kurang Gizi Pada Balita di Komplek Veteran Dusun VIII Kecamatan Percut Sei Tuan dapat ditarik kesimpulan sebagai berikut :

1. Pengetahuan Ibu tentang Kurang Gizi Pada Balita di Komplek Veteran Dusun VIII Kecamatan Percut Sei Tuan mayoritas berpengetahuan Cukup.

2. Sikap Ibu tentang Kurang Gizi Pada Balita di Komplek Veteran Dusun VIII Kecamatan Percut Sei Tuan mayoritas berpengetahuan Cukup.

3. Ada hubungan yang signifikan antara Pengetahuan dengan Sikap Ibu tentang Kurang Gizi Pada Balita di Komplek Veteran Dusun VIII Kecamatan Percut Sei Tuan.Hasil $\mathrm{X}^{2}$ hitung sebesar6,579 menunjukkan bahwa ibu yang memiliki pengetahuan yang baik cenderung 6,579 kali memiliki sikap yang positif mengenai gizi pada balita dibandingkan ibu yang memiliki pengetahuan yang kurang.

\subsection{Saran}

Berdasarkan hasil penelitian diatas saran yang dapat diajukan penulis adalah :

1. Bagi tenaga kesehatan,

Diharapkan kepada tenaga kesehatan bagian pengelola program gizi agar meningkatkan penyuluhan-penyuluhan dan pemberian informasi mengenai pentingnya gizi yang cukup agar tercapai status gizi yang baik untuk balita sehingga angka pravelensi balita gizi kurang bisa diturunkan.

2. Bagi responden, ibu diharapkan mencari sumber informasi tentang asupan makanan bergizi yang baik untuk balitanya sehingga ibu dapat memberikan makanan yang memiliki kandungan gizi seimbang sesuai dengan kebutuhan nutrisi yang harus diberikan kepada balitanya.

3. Bagi peneliti, Perlu dikembangkan lagi penelitian yang sejenis dengan jumlah sampel yang lebih besar dan area penelitian yang lebih luas mengenai status gizis kurang pada balita.

\section{DAFTAR PUSTAKA}

Arikunto, S. (2010). Prosedur Penelittian. Jakarta: Asdi Mahasatya.

Estiwidani, Dwana dkk. (2009). Konsep Kebidanan. Yogyakarta: Fitramaya

Hidayat, A. A. (2010). Metode Penelitian Kebidanan dan Tehnik Analisa Data. Jakarta: Salemba Medika.

Indah. 2014. Pengertian Bid an Menurut IBI http://bidanindah.blogspot.com. Tanggal 15 Maret 2015. Jam 20.08 WIB. 
Khasanah, Nur. (2013). ASI atau Susu Formula ya. Yogyakarta: Flasbook.

Maryunani, Anik. (2012). Inisiasi Menyusui Dini ASI Eksklusif dan Manajemen Laktasi. Jakarta: Trans Info Media.

Machfoedz, Ircham. (2010). Metodologi Penelitian Kuantitatif \& Kualitatif. Yogyakarta: Fitramaya

Notoadmodjo, S. (2010). Ilmu Perilaku Kesehatan. Jakarta: Rineka Cipta.

Notoadmodjo, S.(2010). Promosi Kesehatan Dan Perilaku Kesehatan. Jakarta: Rineka Cipta

Roesli, Utami. (2012). Panduan Inisiasi menyusui dini Plus ASI Eksklusif. Jakarta: Pustaka Bunda.

Yuliati, Nurheti. (2010). Keajaiban ASI Makanan Terbaik Untuk Kesehatan, Kecerdasan, Dan Kelincahan Si Kecil. Yogyakarta: Andi. 